38(11), 1029-1035.

7. Pathmanathan N., Albertini A.-F., Provan P.J. và cộng sự. (2010). Diagnostic evaluation of papillary lesions of the breast on core biopsy. Mod Pathol Off J U S Can Acad Pathol Inc, 23(7), 1021-1028.

8. Ta Thị Minh Phương, Âu Nguyệt Diệu, và Hà
H.T.N. (2015). Đăc điểm giải phẫu bệnh, hóa mô miễn dich trong tổn thương dang nhú tuyến vú. Hoc TP Hồ Chí Minh, 19.

9. Page D.L., Salhany K.E., Jensen R.A. và cộng sư. (1996). Subsequent breast carcinoma risk after biopsy with atypia in a breast papilloma. Cancer, 78(2), 258-266.

\title{
VIÊM MÀNG BỒ ĐÀO TRƯớC CẤP TÍNH DO VIRUS TRÊN NGƯỜI BÊ̂NH KHÔNG MẮC SUY GIẢM MIỄN DICCH
}

\section{TÓM TẮT}

Muc tiêu: mô tả bênh cảnh lâm sàng và đối chiếu với kết quả xét nghiệm PCR thủy dịch của bệnh nhân không bị suy giảm miễn dịch mắc viêm màng bồ đào trước cấp tính Đối tượng và phương pháp nghiên cứu: nghiên cưú mô tả cắt ngang trên 30 bênh nhân bi VMBĐ trước cấp tính 1 bên mắt, lấy dich tiển phòng làm xét nghiêm PCR. Kết quả: 2 mắt có tăng nhãn áp; $100 \%$ bi đau đỏmắt; tỷ lê Tyndall tiên phòng $2+$, $3+$, 4+ lân lượt là $60 \%, 30 \%, 10 \% ; 6 / 30$ ca có kết quả PCR dương tính với CMV tương ứng với tủa trắng, không có ca nào dương tính với virus khác. Kết luận: cân xét nghiêm thường quy PCR dich tiền phòng trên bệnh nhân VMBĐ 1 mắt cấp tính để tìm nguyên nhân, qua đó có thể xác định phương pháp điều trị nguyên nhân hiệu quả.

Tư khóa: viêm màng bồ đào trước cấp, CMV, PCR thủy dịch

\section{SUMMARY \\ VIRAL ACUTE ANTERIOR UVEITIS IN IMMUNOCOMPETENT PATIENTS}

Purpose: Descibe the clinical features of unilateral acute anterior uveitis in the immunocompetent patients and comparing PCR result of humous aqueus sample. Materials and Methods: coss-sectional study, 30 eyes (30 patients) diagnosed of unilateral acute anterior uveitis, were taken the humous aqueus sample in anterior chamber to PCR test. Results: in 30 eyes, 2 eyes $(6,7 \%)$ were hypertonic, $100 \%$ were circumlimbal redness; 6 eyes were CMV + in PCR test regarding white keratic precipitates and none was positive with other virus. Conclusions: PCR test of humous aqueus sample should be the routine exam for unilateral acute anterior uveitis in the immunocompetent patients.

Keyword: acute anterior uveitis, CMV, humous aqueous PCR

\section{I. ĐĂT VẤN ĐỀ}

${ }^{1}$ Bệnh viên Mắt Trung ương

'Sở Y tế Thái Binh

Chịu trách nhiệm chính: Vũ Tuấn Anh

Email: vta.oph@gmail.com

Ngày nhân bài: 9.3.2021

Ngày phản biên khoa hoc: 28.4.2021

Ngày duyệt bài: 7.5.2021

\section{Vũ Tuấn Anh ${ }^{1}$, Hà Trung Kiên ${ }^{2}$}

Viêm màng bồ đào (VMBĐ) trước là một bệnh lý hay gặp nhất viêm nhiễm tổ chức nội nhãn, thường hay tái phát và có nhiều biến chứng, di chứng nặng nề, để lại hậu quả nghiêm trong làm ảnh hưởng đến chức nằng thị giác và cấu trúc nhãn cầu của người bệnh ${ }^{1}$. Việc điều trị VMBĐ trước hầu hết mới chỉ dừng lại ở điều trị triệu chứng và di chứng do không tìm được nguyên nhân gây bệnh rõ ràng.

Năm 2006, các tác giả Schryver, Rozenberg, Cason $x^{2}$ khi nghiên cứu tìm nguyên nhân trên 5 bênh nhân bị VMBĐ trước bằng cách lấy thủy dịch làm phản ứng chuỗi Polymerase (PCR) thì cả 5 trường hợp đều dương tính với Cytomegalovirus (CMV). Khi có bằng chứng về sự có mặt của CMV nội nhãn, 1 số tác giả đã điêu trị nguyên nhân bằng Ganciclovir tiêm nội nhãn cho kết quả khả quan, tỷ lệ khỏi bệnh cao, tỷ lệ tái phát thấp ${ }^{2,5,6,7}$.

Vì vậy, chúng tôi tiến hành nghiên cứu này mục tiêu: Mô tả bệnh cảnh lâm sàng và đối chiếu với kêt quả xét nghiệm PCR thưy dịch của bệnh nhân không bị suy giảm miễn dịch măc viêm màng bồ đào trước cấp tính

\section{II. ĐỐI TƯỢNG VÀ PHƯƠNG PHÁP NGHIÊN CỨU}

2.1. Đối tượng nghiên cứu. 30 bệnh nhân bị VMBĐ trước cấp tính 1 mắt trong 2 nẳm 20162017 đến khám và điều trị tại Bệnh viện Mắt Trung ương.

Tiêu chuẩn lựa chọn bệnh nhân: là những bệnh nhân đã được chẩn đoán xác định VMBĐ trước cấp một mắt, không bị suy giảm miễn dịch.

Tiêu chuẩn loại trừ:

- Những người bệnh già yếu trên 75 tuổi và trẻ dưới 15 tuổi do khó hợp tác trong nghiên cứu, những người có bệnh toàn thân không cho phép tham gia nghiên cứu như mắc bệnh tâm thần, bệnh tăng huyết áp, bênh tim mạch...

- Người bệnh đang có tổn thương viêm, loét giác mac kèm theo.

- Viêm MBĐ thứ phát sau chấn thương đụng 
dập hoặc chấn thương xuyên nhãn cầu.

- Viểm MBĐ trong hội chứng Vogt - Koyanagi

- Harada và trong các bệnh tự miễn khác.

\subsection{Thiết kế và qui trình nghiên cứu}

Nghiên cứu mô tả cắt ngang,

Phương pháp chọn mẫu: chọn mẫu thuận tiện.

Thu thập các thông tin cơ bản: tuổi, giới, thời gian mắc bệnh

Khám mắt

- Thử thị lực có chỉnh kính với bảng thị lực Snellen, đo nhã̃n áp

- Khám bán phần trước thường quy: tình trạng giác mạc, cương tụ rìa, tủa sau giác mạc (vị trí, màu sắc), định lượng tế bào viêm tiền phòng theo phương pháp Tyndall (1+ đến 4+)

- Khám phát hiện tổn thương bán phần sau: sau khi nhỏ giãn đồng tử tối đa khám đáy mắt bằng thấu kính $+90 \mathrm{D}$ kết hợp với sinh hiển vi khám bệnh phát hiện các tổn thương võng mạc.

Đạo đức nghiên cứu: Nghiên cứu tuân thủ các qui tắc đạo đức trong nghiên cứu $\mathrm{Y}$ sinh học, được thông qua Hội đồng đạo đức và được mã hóa, giữ bí mật thông tin của bệnh nhân.

\section{KẾT QUẢ NGHIÊN CỨU VÀ BÀN LUÂN}

Trong thời gian nghiên cứu từ tháng 5/2016 đến tháng $8 / 2017$, chúng tôitiến hành nghiên cứu, thu nhập số liệu và khám 30 mắt của 30 bệnh nhân bị viêm màng bồ đào trước cấp tính đến khám và điều trị tại Bệnh Viện Mắt TW.

\section{1. Đặc điểm của bệnh nhân.}

\subsubsection{Tuổi}

Bảng 3.1. Đặc điểm về nhóm tuổi của bệnh nhân

\begin{tabular}{|c|c|c|}
\hline Nhóm tuối & Số lượng & Tỷ lệ \\
\hline $21-40$ & 14 & 46,7 \\
\hline $41-60$ & 13 & 43,3 \\
\hline$>60$ & 3 & 10,0 \\
\hline Tống & $\mathbf{3 0}$ & $\mathbf{1 0 0 , 0}$ \\
\hline
\end{tabular}

Trong nghiên cứu này chúng tôi gặp bệnh nhân ít tuổi nhất là 21 tuổi, cao tuổi nhất là 63 tuổi, tuổi trung bình của bệnh nhân là 45,6 tuổi, trong đó bệnh nhân dưới 60 tuổi chiếm đa số (90\%). Có 46,7\% số bệnh nhân từ 21- 40 tuổi và $43,3 \%$ số người $41-60$ tuổi.

Xem xét về tuổi của bệnh nhân có thể thấy tỷ lệ bệnh nhân lớn tuổi khá cao (53,3\% trên 40 tuổi - Bảng 3.1). Kết quả này phù hợp với nghiên cứu của Baarsma GS. và cộng sự khi cho rằng tỷ lệ mắc bệnh viêm màng bồ đào trước tăng đáng kể theo tuổi $(p<0,01)^{3}$. Một nghiên cứu của Mỹ ở người cao tuổi cũng cho thấy ở những bệnh nhân từ 65 tuổi trở lên có tỷ lệ viêm màng bồ đào, đặc biệt là viêm màng bồ đào trước khá cao, và chỉ ra gánh nặng bệnh tật của bệnh ở nhóm người cao tuổi ${ }^{1}$. Như vậy tuy số lượng người bệnh nghiên cứu khác nhau, thời điểm và địa điểm nghiên cứu khác nhau, nhưng chúng tôi nhận thấy độ tuổi thường gặp của người bệnh bị viêm MBĐ là tuổi từ 21 trở lển.

Đây là độ tuổi lao động chính, thường có chế độ làm việc, sinh hoạt cần đến sự tập trung cao độ của mắt Những người trong độ tuổi này cũng hay phải thức khuya đọc sách báo, tài liệu, nghiên cứu học tập. Mặt khác đây cũng chính là độ tuổi có, nhiêu áp lực xã hội và trong công việc dễ dẫn đến sự căng thẳng, lo lắng gây nên những xúc động tinh thần từ đó gây nên những stress tâm lý kích hoạt virus ở trạng thái ẩn hoạt động gây bệnh.

Về giới tính, nhóm bệnh nhân chia đều 15 nam, 15 nữ. Trong nghiên cứu này, tỷ lệ bệnh nhân nam và nữ là cân bằng với $50 \%$ ở mỗi giới. Tương tự, nghiên cứu về dịch tễ bệnh VMBĐ ở Bắc Mỹ cũng cho tỷ lệ $56,6 \%$ số bệnh nhân là nữ ${ }^{3}$. Một nghiên cứu khác của Baarsma GS cũng chỉ ra rẳng không có mối liên quan giữa giới tính với tình trạng mắc viêm màng bồ đào ${ }^{3}$.

Bảng 3.2. Đặc điểm các triệu chứng chủ quan

\begin{tabular}{|c|c|c|}
\hline Triệu chứng & Số lượng & Tỷ lệ \\
\hline Đau nhức & 30 & 100,0 \\
\hline Nhìn mờ & 20 & 66,7 \\
\hline Chảy nước mắt & 10 & 33,3 \\
\hline Đó mắt & 30 & 100,0 \\
\hline
\end{tabular}

Như vậy có $100 \%$ bệnh nhân viêm màng bồ đào trước trong nghiên cứu có triệu chứng đau nhức và đỏ mắt. Tỷ lệ bệnh nhân có nhìn mờ là $66,7 \%$; có $1 / 3$ số người có chảy nước mắt (33,3\%).

Các dấu hiệu và triệu chứng của viêm màng bồ đào phụ thuộc vào loại viêm ${ }^{4}$ Tuy nhiên các triệu chứng thường gặp là mờ mắt, đau mắt, đỏ mắt, chảy nước mắt, nhạy cảm với ánh sáng ${ }^{4}$. Trong nghiên cứu này, tất cả bệnh nhân viêm màng bồ đào trước có triệu chứng đau nhức và đỏ mắt. Tỷ lệ bệnh nhân có nhìn mờ là $66,7 \%$; có $1 / 3$ số người có chảy nước mắt $(33,3 \%)$. Kết quả này có những tương đồng với kết quả trong nghiên cứu của Rothova $A$. và cộng sự, cụ thể, khi thực hiện nghiên cứu trên 69 bệnh nhân có viêm màng bồ đào, tỷ lệ có đỏ mắt là $99 \%$, đau mắt là $80 \%$; mờ mắt $43 \%$ và $25 \%$ có chảy nước mắt 4 .

Bảng 3.3. Tyndall tiền phòng

\begin{tabular}{|c|c|c|}
\hline Tyndall & Số lượng & Tỷ lệ \\
\hline $2+$ & 18 & 60.0 \\
\hline $3+$ & 9 & 30.0 \\
\hline $4+$ & 3 & 10.0 \\
\hline
\end{tabular}

Nhận xét: Tyndall tiên phòng phổ biến nhất là $2+$ với $60 \%$; còn lại $30 \%$ là $3+$ và $10 \%$ là $4+$. 


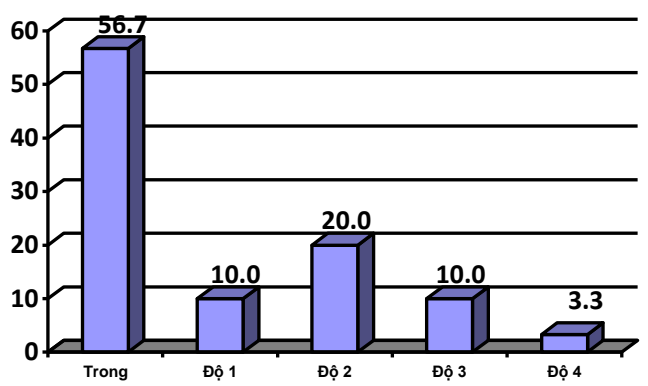

Biểu đồ 3.1. Phân bố tình trạng đục thủy tinh thê.
Đa số các trường hợp có thủy tinh thể còn trong $(56,7 \%)$. Tỷ lệ đục thủy tinh thể độ $1,2,3$ và 4 lần lượt là $10 \% ; 20 \% ; 10 \%$ và $3,3 \%$. Thể mãn tính hoăcc tái phát của viêm màng bồ đào có thể gặp biến chứng đục thủy tinh thể như một hậu quả của quá trình viêm hoặc dùng cortisteroid. Trong những viêm màng bồ đào cấp nặng cũng có thể có tình trạng thể thủy tinh đục trương phồng hoặc mất tính trong suốt [43]. Nghiên cứu của chúng tôi đa phần thủy tinh thể còn trong là do bệnh nhân trong nghiên cứu chủ yếu là tuổi còn trẻ và bênh mới mắc, tái phát ít nên chưa có biến chứng hay di chứng đục thủy tinh thể.

Bảng 3.4. Môi liên quan giứa CMV với màu sắc tủa sau giác mạc

\begin{tabular}{|c|c|c|c|c|c|c|}
\hline \multirow{2}{*}{ Màu sắc CMV } & \multicolumn{2}{c|}{ Dương tính (N=6) } & Âm tính (N=24) & \multicolumn{2}{c|}{ Tống (N=30) } \\
\cline { 2 - 7 } & $\mathrm{SL}$ & $\%$ & $\mathrm{SL}$ & $\%$ & $\mathrm{SL}$ & $\%$ \\
\hline Trắng & 6 & 27,3 & 16 & 72,7 & 22 & 100,0 \\
\hline Nâu & 0 & 0,0 & 8 & 100,0 & 8 & 100,0 \\
\hline
\end{tabular}

Tất cả bệnh nhân có tủa sau giác mạc màu nâu đều âm tính với CMV; tỷ lệ dương tính ở bệnh nhân có tủa giác mạc trắng là $27,3 \%$.

Theo các chuyên gia, tủa giác mạc mới có màu trắng kem, bờ mờ. Trong giai đoạn viêm màng bồ đào ổn định, tủa giác mạc ngả màu

nâu do có sắc tố, tủa có khía và nhỏ lại (tủa cũ). Có thể thấy tủa giác mạc trong nghiển cứu chủ yếu là tủa mới. Kết quả này phù hợp với thống kê trước đó cho thấy thời gian mắc bệnh hầu hết dưới 1 tháng và đa số là bệnh nhân mới mắc, chỉ có rất ít bệnh nhân tái phát bệnh ${ }^{4,5,7}$.

Bảng 3.5. Môi liên quan giữa CMV với tình trạng tyndall tiền phòng

\begin{tabular}{|c|c|c|c|c|c|c|}
\hline \multirow{2}{*}{ Tyndall CMV } & \multicolumn{2}{|c|}{ Dương tính (N=6) } & \multicolumn{1}{c|}{ Ám tính (N=24) } & \multicolumn{2}{c|}{ Tống (N=30) } \\
\cline { 2 - 7 } & $\mathrm{SL}$ & $\%$ & $\mathrm{SL}$ & $\%$ & $\mathrm{SL}$ & $\%$ \\
\hline $2+$ & 2 & 11,1 & 16 & 88,9 & 18 & 100,0 \\
\hline $3+$ & 3 & 33,3 & 6 & 66,7 & 9 & 100,0 \\
\hline $4+$ & 1 & 33,3 & 2 & 66,7 & 3 & 100,0 \\
\hline
\end{tabular}

Tỷ lệ dương tính với CMV ở bệnh nhân có Tyndall $2+$ là $11,1 \%$ và cùng bằng $33,3 \%$ ở người bệnh có Tyndall 3+ và 4+.

Ở bểnh viêm màng bồ đào, thủy dịch trong tiền phòng có protein biểu hiện bằng dấu hiệu Tyndall dương tính, tiền phòng có thể có fibrin hoặc mủ gồm bạch cầu đa nhân và tế bào hoại tử. Các mức độ Tyndall được xác định như sau: Tyndall 1+: thủy dịch đục rất nhẹ; Tyndall 2+: thủy dịch đục vừa phải, còn soi rõ chi tiết mống mắt và thể thủy tinh; Tyndall $3+$ : thủy dịch đục

nhiều, không soi rõ chi tiết mống mắt và thể thủy tinh; Tyndall 4+: thủy dịch đục rất nhiêu, có fibrin ${ }^{4,5}$. Kết quả nghiên cứu cho thấy, Tyndall tiền phòng phổ biến nhất là $2+$ với $60 \%$; còn lại $30 \%$ là $3+$ và $10 \%$ là $4+$. Các chuyên gia cho rằng khi còn dấu hiệu Tyndall chứng tỏ viêm màng bồ đào đang trong đợt cấp ${ }^{5}$. Như vậy kết quả nghiên cứu khá phù hợp do đối tượng nghiên cứu là những bệnh nhân viêm màng bồ đào trước cấp tính.

\section{Bảng 3.6. Môi liên quan giứa CMV với tình trạng nhãn áp}

\begin{tabular}{|c|c|c|c|c|c|c|}
\hline \multirow{2}{*}{ Nhãn áp CMV } & \multicolumn{2}{c|}{ Dương tính (N=6) } & Âm tính (N=24) & \multicolumn{2}{|c|}{ Tổng (N=30) } \\
\cline { 2 - 7 } & $\mathbf{S L}$ & $\mathbf{\%}$ & $\mathbf{S L}$ & $\mathbf{\%}$ & $\mathbf{S L}$ & $\mathbf{\%}$ \\
\hline Bình thường & 5 & 17,9 & 23 & 82,1 & 28 & 100,0 \\
\hline Cao & 1 & 50,0 & 1 & 50,0 & 2 & 100,0 \\
\hline
\end{tabular}

Nhận xét: trong 2 bệnh nhân có nhãn áp cao, có 1 bệnh nhân CMV.

Đối tượng nghiên cứu của chúng tôi đều loại trừ các trường hợp có tổn thương hệ thống miễn dịch Kết quả nghiên cứu của chúng tôi cũng phù hợp với tác giả Soon Phaik Chee và cộng sự sau quá trình nghiên cứu với các kết quả thu được, tác giả đã đưa ra kết luận viêm MBĐ trước do CMV không phải là hiếm thấy ở bênh nhân có miễn dịch bình thường và nó có thể như là đợt 
tái phát cấp hoặc viêm mạn tính ${ }^{5}$.

Nhiễm virus được xem là một trong những nguyên nhân nhiễm khuẩn của bệnh viêm màng bồ đào và CMV là loại virus phố biến được tìm thây ở những bệnh nhân viêm màng bồ đào. Trên cơ thể người, CMV nhân lên trong tế bào của nhiều cơ quan như tế bào tuyến nước bọt, tế bào gan, thận, phổi. Đặc điểm cơ bản của bệnh do CMV gây ra là những thể vùi khổng lồ trong nhân tế bào bị nhiễm. CMV có ba hình thái nhiễm trùng là gây hủy hoại tế bào (bệnh cấp tính), tiềm tàng và nhiễm virus thể ẩn? Năm 2006, Schryver, F. Rozenberg, N. Casonx và cộng sự khi lấy dịch tiền phòng của 5 bệnh nhân bị viêm MBĐ trước làm PCR thì cả 5 trường hợp đều dương tính với CMV, không thấy có sự xuất hiện của các virus khác như Herpes Simplex virus (HSV), Herpes Zoster virus (HZV) hay Rubella trong thủy dịch của những bệnh nhân này ${ }^{2}$. Kết quả nghiên cứu của chúng tôi cho thây có $20 \%$ số trường hợp dương tính với CMV khi làm xét nghiệm PCR thủy dịch của bệnh nhân viêm màng bồ đào trước cấp tính. Kết quả này tương đồng với nghiên cứu của Soon Phaik Chee và cộng sự thực hiện trên 105 mắt bệnh nhân bị viêm $\mathrm{MB}$ Đ trước, bằng cách làm phản ứng $\mathrm{PCR}$ dịch tiền phòng đã thấy có 24 bệnh nhân (22,8\%) dương tính với CMV5.

Các thống kê trong nghiên cứu cũng cho thấy tỷ lệ bệnh nhân dương tính với CMV lần lượt ở các nhóm tuổi $21-40 ; 41-60$ và trên 60 tuổi là $21,4 \% ; 15,4 \%$ và $33,3 \%$. Có vẻ như tỷ lệ mắc viêm màng bồ đào với sự có mặt của CMV cao nhất ở những người lớn tuổi (>60 tuổi). Các chuyên gia cũng cho rằng nhiễm $\mathrm{CMV}$ ở người lớn là khá phổ biến, tỉ lệ nhiễm CMV tăng dần từ thời thơ ấu đến tuổi thành niên ${ }^{3,5}$. Điều này cũng phù hợp khi sức đề kháng giảm dần ở người lớn tuổi và người già, tạo điều kiện cho sự xâm nhập và phát triển của các virus.

Bệnh nhân viêm màng bồ đào trước cấp tính có tỳ lê dương tính với $\mathrm{CMV}$ phù hợp với các triệu chứng lâm sàng như: bệnh có xu hướng xuất hiện đơn độc, hay tái phát tự nhiên và liên quan đến tăng nhãn áp hơn $40 \mathrm{mmHg}$ ở nhiều bệnh nhân; những bệnh nhân ở độ tuổi từ 20 đến 40 có thể bị nhìn mờ, đau mắt và đau đầu, và khoảng $2 / 3$ số bệnh nhân có vấn đề này là nam giới ${ }^{5,7}$. Tuy nhiên, tác giả Van Boxtel lại cho rằng đa số người bị nhiễm CMV không có triệu chứng lâm sàng. Các cá thể có biểu hiện lâm sàng thường là các đối tượng có nguy cơ cao nhất như bị nhiễm ở thời kỳ chu sinh, điều trị ức chế miễn dịch, truyền máu hoặc ghép cơ quan. Có thể thây rằng, mối liên quan giữa viêm màng bồ đào do nhiếm CMV và các triệu chứng lâm sàng còn khá mơ hồ7. Khi mà các triệu chứng lâm sàng không rõ ràng hay không đủ mạnh để làm căn cứ xác định nguyên nhân gây bệnh thì việc sử dụng các xét nghiệm cận lâm sàng trở lên vô cùng hữu dụng khi xác định chính xác được nguyên nhân gây bệnh để từ đó có hướng điêu trị theo nguyên nhân rõ ràng.

\section{KẾT LUÂNN}

VMBĐ trước là một bệnh thường gặp và nguy cơ có nhiều biến chứng, bên cạnh đó, điều trị lại thường khó khăn, hay tái phát. Việc tìm ra nguyên nhân gây bệnh (nhiễm virus, vi khuẩn, kí sinh trùng ...) có ý nghĩa to lớn trong định hướng điều trị cũng như tiên lượng bệnh, đặc biệt là nhóm những bệnh nhân không bị suy giảm miễn dịch. Tại Việt Nam, cho đến nay việc lấy dịch tiền phòng làm phản ứng PCR để tìm nguyên nhân cho bệnh nhân bị viêm màng bồ đào trước cấp tính vẫn rất hiếm khi được áp dụng. Vì vậy, nên thực hiện rộng rãi xét nghiệm PCR thủy dịch đối với bệnh nhân VMBĐ trước cấp tính như là xét nghiệm thường quy, nhằm tăng khả năng chẩn đoán nguyên nhân và hiệu quả điều trị bệnh.

\section{TÀI LIÊU THAM KHẢO}

1. Rothova A, Suttorp - Schulten MSA, Treffers WF, Kijlstra A. Causes and frequency of blindness in patients with intraocular inflammatory disease. Br J Ophthalmol. 1996;80:332-6.

2 F. Rozenberg De Schryver, N Casonx (2006). Diagnosis and treatment of CytoMegalovirus iridocyclitis without retinal necrosis. $\mathrm{Br} \mathrm{J}$ of Ophthalmol 2006; 90 805-805

3. Baarsma GS. The epidemiology and genetics of uveitis. Current Eye Research. 1992;11:1-9

4. Rothova A, Van Veenendaal $W$, Linssen AGlasius $E$, Kijlstra A, de jong P. Clinical features of acute anterior uveitis. Am J Ophthalmol. 1987;103:137-45.

5. Soon Phaik Chee, Kristine Bacsal. Clinical Features of CytomegaloVirus Anterior Uveitis in immunocompetent patient. Am J Ophthalmol 2008;145:834-840..

6. H. Mietz, S. Aisenbrey, K. U. Bartz-Schmidt, S. Bamborschke. Ganciclovir for the treatment of anterior uveitis. Graefes Arch clin Exp ophthalmol 2000, 238, 905 - 909.

7. Van Boxtel, L. A. A., van der Lelij, A., van der Meer, J., \& Los, L. I. Cytomegalovirus as a Cause of Anterior Uveitis in Immunocompetent Patients. Ophthalmology $2007,114(7), 1358-1362$. 